\title{
Crossing Cultures: Guides and Models for Development, Selection, and Application
}

\author{
Robert W. Service \\ Samford University \\ C. Clifton Eason \\ Samford University
}

David Sonius

Flint CPS Inks

\section{Kavore Kariuki \\ KGroup Consultants}

\author{
Joseph Worcester \\ Silk Road Start Global Study Programs
}

Despite many calls for it, there has been little action toward an all-inclusive manuscript that is practical, empirically verified, and provides guidelines for becoming and remaining strategically culturally adaptive. Further, a tremendous number of current articles and books emphasize managing or leading in an era of globalization. To meet these calls to work, learn, and innovate across cultures, the goal must be to move from the mass of unrelated assertions to the weaving of co-created, manageable models that are useful in learning, teaching, and practice.

\section{INTRODUCTION}

Whereas previous generations have focused on addressing weakness, the focus in the $21^{\text {st }}$ century has been on strengths (Buckingham \& Clifton, 2001). Additionally, we often talk about emotional intelligence and an emphasis on eliminating biases while providing a consistent message across cultures. Indeed, leaders and managers need to be able to cross multiple cultures and provide consistent, objective goals and accountability (Bell et al., 2018; Powell, 2017). Accordingly, our guiding Global Leadership Quotient Model (GLQ) has proven to be vastly useful in classes and in selecting and preparing for cross-cultural experiences. Further, the GLQ provides a good base for ongoing evaluation and improvement (Service, Loudon, \& Kariuki, 2014; Service \& Reburn, 2014). GLQ aims to help people continuously 
improve in becoming and remaining culturally adaptive as they work, manage, lead, and enjoy across many norms and rules.

\section{THE LITERATURE}

One cannot explore this topic without noting that there is much in the composite extant literature that could be used to advance thinking in culturally adaptive behaviors. As such, we must narrow our focus in this research. That said, we assure readers that we have included as much as feasible, and our coverage has left few stones unturned. All too much of what we see in so many areas of social science academic research is too narrow or so academically slanted that it is unusable for a practitioner. Meanwhile, the popular press and instructive literature can be so broad and delineate so many rules that it becomes of little use. We intend to fill this gap with a model that incorporates an appropriate amount of detail while recognizing that it must be simple enough to be practical. We start with the case for a cultural imperative of adaptability. There is no single "best way," and there is no perfect model. However, the GLQ presented here is useful for evaluation and improvement.

Initial cross-cultural experiences teach more about one's own cultures than about new or others' cultures. Those that have not crossed cultures simply cannot know, with proper context, what entails their own culture. We start with a few simple points. First, cultural norms for words, thoughts, actions, and thought vary and occur at many levels - from locally at home to globally abroad. The units of analysis include corporations, tribal units, cities/villages, and more. Second, in an ordinary day, one may cross cultures several times doing business. For example, in a single day, a salesperson may communicate with a NASCAR lover in Alabama, a boutique dress shop owner in Eastport, Maine, human rights advocate in San Francisco, and a Texas cowboy. And these same lables could have been applied in any of the other locales (e.g., a cowboy in Maine). Diversity is the norm, and these examples are just for the Unites States. Many other countries and even cities are too large and diverse to have a single culture. Third, to learn more about one's own culture, that person must experience another culture. Fourth, cultural norms are generally not good or bad; they are just different. Fifth, it is difficult to lead under diverse norms without totally avoiding your principles. Sixth, even those unavoidable and necessary standbys of truth and trust can be different according to where you are, who you are, and who they are. Finally, we concur with Trompenaars and Hampden-Turner (2012) that ethnic differences within societies, such as "South African and, to a lesser degree, the US can be as big as international difference" (p. 341). This speaks to the importance of understanding the implications of crossing cultures regardless of whether or not one plans to go abroad.

There is so much in the extant literature that could be of help when one crosses cultures in a high stakes business context. If one is in that high stakes situation, such literature can be a valuable tool. But we suggest strongly several readings (their key points are included in this manuscript) and encourage spending considerable time reviewing some general works that we have curated and condensed: 1) Dobelli's (2013) book on thinking clearly; 2) Elmer's (2002) book that stresses "just different" thinking; 3) Haidt's (2012) book on why good people think differently; 4) Mendenhall et al.'s (2008) review of global leadership research; 5) Brooks (2011), Chopra and Mlodinow (2011), Hall (2011), Pinker (1997, 2002, 2011), Sternberg (1985, 1988, 1996, 2003), or even Frankl's (2006) Man's Search for Meaning demonstrate what it means to be human and exhibit wisdom regardless of culture; 6) Service and Arnott's (2006) work on the $L Q^{\odot}$; 7) Trompenaars and Hampden-Turner (2012) bringing it together with examples that provide understanding over categorization; 8) HBR's 10 Must Reads: On Managing Across Cultures (2016); and 9) our derived Global Leadership Quotient (GLQ) Models for measuring and improving cross-cultural intellect. We contend that our research gives readers a more comprehensive and logical approach to measuring and improving one's self and others as they cross cultures.

\section{Thinking Clearly—a Guide}

Here we are fortunate to have found Dobelli's (2013) The Art of Thinking Clearly - an easy read with 99 chapters of three pages each that describe the more common cognitive biases. Cognitive bias \#1 
manifests itself when we make up our minds quickly and seek only confirming evidence. This and many other preferences guide all our thinking preferences (predispositions) that are used in our considerations of arguments, frames of reference and mental models, to guide our views of others and cultures, and to direct our judgments and actions - thus helping us determine and justify our place in the world. Our cognitive biases often keep us in our known and unknown ignorance (unawareness). These mental favoritisms and misguided interpretations can keep us from innovating and creating new and different products, organizations, selves, or approaches. Dobelli's aim is to help readers learn to recognize and evade the biggest errors we have in thinking in order to improve our personal and work lives as well as our organizations.

Table 1 has all 99 biases broken into three domains: cognitive biases, psychological biases, and matharithmetic biases. Further, Table 2 has a partial list of the biases with brief descriptions. We encourage readers to reflect on what these mean at a personal level. The primary foundation for successfully crossing cultures is the elimination - or at least recognition - of the need to identify and control biases.

TABLE 1

NORMAL BIASES

(MODIFIED DIRECTLY FROM DOBELLI'S (2013) 99 COGNITIVE BIASES)

\begin{tabular}{|c|c|c|}
\hline Cognitive & Psychological & Math-arithmetic \\
\hline $\begin{array}{l}\text { 1. Survivorship-be the } \\
\text { example } \\
\text { 2. Authority-not outside } \\
\text { expertise } \\
\text { 3. Story-is incomplete or } \\
\text { slanted } \\
\text { 4. Hindsight-not } 20-20 \\
\text { 5. Outcomes-exception not } \\
\text { rule } \\
\text { 6. Coincidence-they } \\
\text { happen } \\
\text { 7. Scarcity-not always of } \\
\text { value } \\
\text { 8. Base rate neglect-hear } \\
\text { the good } \\
\text { 9. Anchor-to dates, times, } \\
\text { places } \\
\text { 10. Induction-may not } \\
\text { continue } \\
\text { 11. Winners' circle-not } \\
\text { always again } \\
\text { 12. Fundamental attribution } \\
\text { error } \\
\text { 13. False causality } \\
\text { 14. Alternatives-no to path } \\
\text { not taken } \\
\text { 15. Forecast illusion } \\
\text { 16. Alternative with less } \\
\text { conditions } \\
\text { 17. Framing-distorted } \\
\text { 18. Action preference }\end{array}$ & $\begin{array}{l}\text { 1. Swimmer's body-born } \\
\text { not made } \\
\text { 2. Clustering-look for } \\
\text { patterns } \\
\text { 3. Social proof-everyone } \\
\text { does it } \\
\text { 4. Reciprocity-seek } \\
\text { equality } \\
\text { 5. Confirmation-to support } \\
\text { mind } \\
\text { 6. Availability-easy to get } \\
\text { 7. No-pain, no-gain } \\
\text { 8. Story-want it to be true } \\
\text { 9. Overconfidence- } \\
\text { reasons? } \\
\text { 10. Chauffer knowledge- } \\
\text { superficial } \\
\text { 11. Illusion of control } \\
\text { 12. Super response to } \\
\text { incentives } \\
\text { 13. Paradox of too many } \\
\text { choices } \\
\text { 14. Liking \& likability } \\
\text { 15. Endowment-clinging to } \\
\text { things } \\
\text { 16. Coincidence-want it to } \\
\text { be } \\
\text { 17. Group think } \\
\text { 18. Lose aversion-over } \\
\text { winning } \\
\text { 19. Social loafing-catching }\end{array}$ & 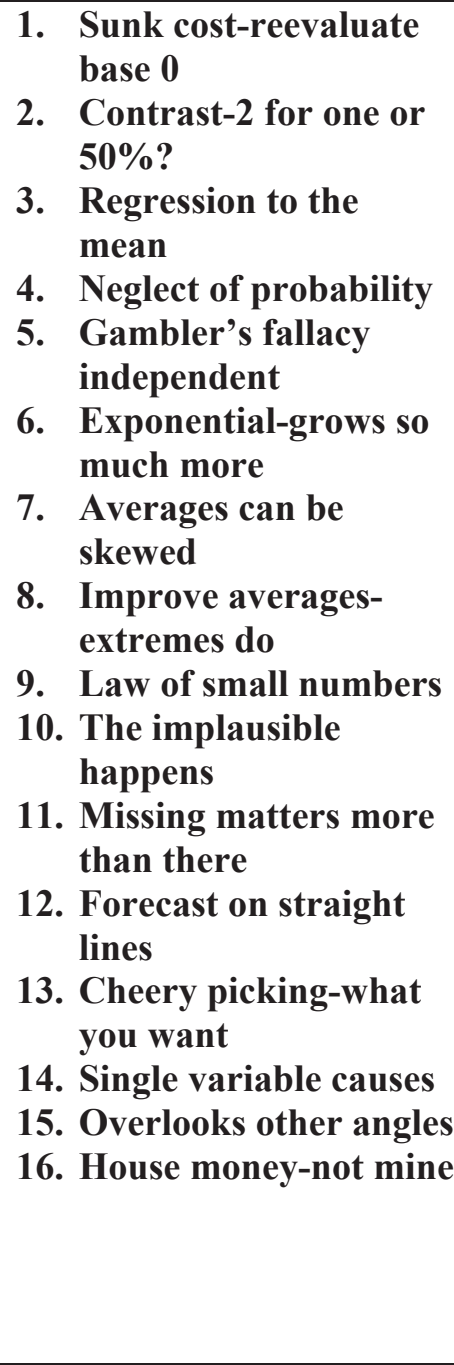 \\
\hline
\end{tabular}




\begin{tabular}{|c|c|}
\hline $\begin{array}{l}\text { 19. Self-serving selection } \\
\text { Association-Pavlov's } \\
\text { dog } \\
\text { 20. Beginners luck } \\
\text { 21. Value the immediate } \\
\text { 22. Decision fatigue-many } \\
\text { choices } \\
\text { 23. Amount of information } \\
\text { 24. Value new or different } \\
\text { 25. Alternatives-create } \\
\text { dichotomies } \\
\text { 26. Primacy \& recentcy } \\
\text { effects } \\
\text { 27. Domain-not between } \\
\text { disciplines } \\
\text { 28. Salience effect- } \\
\text { noticeable, main, } \\
\text { 29. Illusion of attention } \\
\text { 30. Hot air } \\
\text { misrepresentation } \\
\text { 31. Overthinking } \\
\text { 32. Planning-take on too } \\
\text { much } \\
\text { 33. News allusion-may not } \\
\text { be right } \\
\text { 34. Falsification of history } \\
\text { 35. Ambiguity aversion- } \\
\text { may be } \\
\text { 36. Take the default } \\
\text { 37. Illusion of skill } \\
\text { 38. Simple over complex }\end{array}$ & $\begin{array}{l}\text { 20. Halo effect-attractive } \\
\text { 21. Hedonic treadmill-what } \\
\text { you wish } \\
\text { 22. Self selection-why me } \\
\text { 23. Cognitive dissonance- } \\
\text { retrospect } \\
\text { 24. Because-addicted to } \\
\text { because } \\
\text { 25. Contagion-it's } \\
\text { associated with } \\
\text { 26. Motivation crowding- } \\
\text { too many } \\
\text { 27. Twaddle-jabber to } \\
\text { disguise } \\
\text { 28. Effort-worked so hard, } \\
\text { but. } \\
\text { 29. Expectations-not real \& } \\
\text { fail } \\
\text { 30. Exposing charlatan- } \\
\text { astrology! } \\
\text { 31. Volunteers' folly-takes } \\
\text { job/pay } \\
\text { 32. Puppets to emptions } \\
\text { 33. Introspective-can be } \\
\text { right or not } \\
\text { 34. Inability to close doors } \\
\text { 35. Sleeper effect- } \\
\text { propaganda works } \\
\text { 36. Social comparison- } \\
\text { against betters } \\
\text { 37. Not invented here } \\
\text { 38. False consensus } \\
\text { 39. In-out groups } \\
\text { 40. Fear or regret } \\
\text { 41. Procrastination } \\
\text { 42. Envy } \\
\text { 43. Personification- } \\
\text { representative? } \\
\text { 44. Opinion of persona- } \\
\text { more than }\end{array}$ \\
\hline
\end{tabular}




\section{TABLE 2 \\ TRUNCATED BIASES WITH DESCRIPTIONS (MODIFIED DIRECTLY FROM DOBELLI'S (2013) 99 COGNITIVE BIASES)}

\begin{tabular}{|c|c|}
\hline Bias & Short Description \\
\hline Survivorship & Only see and hear about successes. \\
\hline $\begin{array}{l}\text { Swimmer's body } \\
\text { illusion }\end{array}$ & They are made for it, not because of it. \\
\hline $\begin{array}{l}\text { Clustering } \\
\text { illusion }\end{array}$ & Creating patterns out of randomness \\
\hline Social Proof & Even if 50 million people say something foolish, it is still foolish. \\
\hline Sunk cost & Evaluate higher because of what you have in it \\
\hline Reciprocity & Don't accept free stuff when you think you are going to get asked for something. \\
\hline Confirmation & We are great at assessing all information so that our prior conclusions remain. \\
\hline Authority & Experts know little outside of their expertise and favor that. \\
\hline Contrast & If you think it's a good deal - buy one get one absolutely free, really? \\
\hline Availability & We tend to only use information or examples that are easy for us to get. \\
\hline No pain, no gain & We almost killed ourselves so it must be good. \\
\hline Story & We shape everything we tell-no one is a $100 \%$ objective-perspective. \\
\hline Hindsight & It's easy to say why or what in retrospect. \\
\hline Overconfidence & We tend to be more confident with limited information-ignorance and confidence! \\
\hline $\begin{array}{l}\text { Chauffer } \\
\text { knowledge }\end{array}$ & Only having superficial knowledge of a topic. \\
\hline Illusion of control & Lottery tickets - trying to control what we have no control over. \\
\hline $\begin{array}{l}\text { Incentive super- } \\
\text { response }\end{array}$ & Unexpected over response to incentive. \\
\hline $\begin{array}{l}\text { Regression to the } \\
\text { mean }\end{array}$ & All things tend to return to the average over time. \\
\hline Outcome & The randomness of a random outcome is just random. \\
\hline Paradox of choice & Too many choices confuse and make harder to decide. \\
\hline Liking & Being likeable or liking something. \\
\hline $\begin{array}{l}\text { Endowment } \\
\text { effect }\end{array}$ & Money is there so spend it. \\
\hline Coincidence & Are rare. \\
\hline Groupthink & We think differently in groups. \\
\hline $\begin{array}{l}\text { Neglect of } \\
\text { probability }\end{array}$ & Probabilities count/understand real ones. \\
\hline Scarcity & Just because it is rare, does not always mean value. \\
\hline Base-rate neglect & See extremes not real rates. \\
\hline Gambler's fallacy & No balancing effect in independent events. \\
\hline Anchor & False or meaningless base used to evaluate from. \\
\hline Induction & Inductive reasoning has limits too. \\
\hline Loss aversion & Favor avoiding loss over possible gains. \\
\hline
\end{tabular}

\section{The Perceived Complexity of Mathematics}

Fortunately, mathematics is a language without bias or cultural boundaries. Unfortunately, many westerners live in a world that accepts mathematical ignorance, leading us to being easily mislead. When mathematical ignorance is coupled with normal self-serving predispositions, the validity of empirical 
findings must be viewed with high levels of skepticism and a deep knowledge base. Supporting this supposition, a recent study recounted in the Wall Street Journal found that the findings in a majority of peer-reviewed scientific journal articles cannot be replicated. This is a major obstacle in being able to suggest that one's findings are highly generalizable and, therefore, practical to a large audience. When considering the question of there being no alternative explanations for a phenomenon, it becomes essentially impossible to "prove" anything from a scientific perspective. "The chief cause of irreproducibility may be that scientists, where wittingly or not, are fishing fake statistical significance out of noisy data" (Wood \& Randall, 2018, p. A17). We note this often happening in studies that tout findings from small and/or convenience samples. Sadly and tellingly, "The social psychology that informs education policy could be entirely irreproducible" (p. A17). When we examine much of what social scientists study and produce in academically refereed empirical studies, there is little evidence that we have proven almost anything of use in managing and leading in the ever-evolving, globally competitive landscape. Too much of what we read and even teach "was true in a misleading sense only" (Blinder, 2018, p. A13)."

We see misleading statistics in economic reports and publicity. Corporate income tax "rates" in America (prior to the Trump tax cuts of 2018) were the highest in the free world. While a fact, in reality, no organization in America pays that highest rate (Blinder, 2018). Notably it would take less than 1\% of total corporate revenue in America to replace all of the corporate income tax actually collected annually in America (Statistics of Income, 2013). Economists and statisticians often "prove" what they want to instead of providing clear views from multiple angles. The deranged gunman who targeting American Congressmen in June, 2017 railed that the top 1\% for not paying their fair share. Yet the top $0.17 \%$ pay over $20 \%$ of income tax, the top $12 \%$ pay about $75 \%$, and the bottom $66 \%$ ( $\$ 50 \mathrm{~K}$ income and less) pay $7.5 \%$ (Service \& Reburn, 2016). These examples show the power of big data and analytics; we should follow the data - not our emotions.

Too often, we focus on independent or isolated events. False numerical comparisons and number bias are common. Small samples are used to make conclusions without reference to margin of error. And inadequate math skills are too often an excuse to defining the wrong issue or defining the right issue wrongly. There is no shortage of data; yet there is a profound lack of context and understanding. This leads to a sense of knowing when, in fact, ignorance abounds.

\section{How Can "Good" Intelligent People Think So Differently?}

We can all describe a "bad" manager - including the experiences of the authors (IS/IT, banking, academia, international production-distribution, healthcare, government-management and leadership). Haidt's The Righteous Mind (2012) describes clearly why good smart people can have such radically different dividing opinions on work, politics, and religion. Related to our current attempt to succeed in different cultures, Haidt reminds us of the importance of: 1) reciprocity; 2) thought experiments (prethinking how actions will play out); 3) thinking to learn (also Albrecht, 2003); 4) addressing conformational biases; 5) allowing for intuitions leading logic; 6) realizing and using innate understanding forms the first draft of life's beliefs and actions; 7) stressing the notion of shared intentionality; 8) development of wisdom from the knowledge that morality binds but also blinds; 9) realizing that evolution can be fast, as genes and cultures coevolve; 10) showing that innate does not mean unmalleable (rather, it means organized in advance of experience); 11) noting useful pronouncements in books, analogies, research - empirical or otherwise; and 12) admitting and using facts that "Markets Are Miraculous."

Understanding Haidt's first principle of moral psychology, "Intuitions come first and strategic reasoning second" (p. 82, bolding ours) is key in handling differences more effectively. A careful individual will see that much of the dichotomous thinking about selfish genes and economic self-interest logic versus societal collaborations and greater good sacrifices can be reconciled and better understood when one considers the benefits of reciprocity that cultural norms provide. Yes, innovations and collaborations follow self-interest (Colino, Benito-Osorio, \& Armengot, 2014; Collins, 2001, 2003). A "moral life is really about cooperation and alliances, rather than about power and domination. Dishonesty 
and hypocrisy of our moral reasoning is done to get people to like us and cooperate with us..." (p. 392). Morality is, in a large part, an evolved solution to the free rider problem" (p. 412). Societal norms have evolved to punish cheaters and provide pleasure in revenge. These points need to be considered in light of the strength of confirmation bias directing innate conclusions that precede unbiased logical reasoning.

The key point here is to not assume that those in other cultures are wrong and that we are right. We should recognize the "just different" of cultures and how understanding can enable us to remain simultaneously open and cautious as we witness actions, read, or hear things we may have never considered. Yes, highly intelligent people do think differently about the same topics given the same facts. Study literature that helps orientate learners to biases, cultural norms, and why cultures think differently.

\section{The Leadership Quotient $\left(\mathrm{LQ}^{\odot}\right)$}

The next section is based largely on Service and Reburn's (2014) "Leadership for Innovation: Fundamentals of Human Influence" and Service and Arnott's (2006) $L Q^{\odot}$. The research into developing this quotient for leadership started in the late 1990s as the authors attempted to find texts useful in selfassessment and improvement and that were useful as measurements for the teaching and development of leaders. Finding that there was no single unified model of leadership, Service and Arnott's book provided some 192 percepts divided by well-known and new quotients. Here, the current authors recount some of the $L Q^{\mathcal{C}}$ development that has been well-vetted in at least 30 academically refereed articles, used in many consulting assignments, and with scores of students at the undergraduate and graduate level. $L Q^{\odot}$ is a sturdy bridge to the development of the GLQ, which is the $L Q^{\odot}$ for crossing cultures.

\section{The Meat of $L Q \subset$}

The $L Q \odot$, as depicted in the formula in Figure 1, came from over 1,100 respondents having an average of 15 years of working experience and 17 years of education). In addition, it borrows from the authors' over 50 years of combined personal experiences and observations, and thousands of published sources (Service \& Arnott, 2006), and evolved over 10 years.

The leadership model development started with research in the areas of the IQ, EQ, and related psychological and instructive literature in an attempt to go beyond the "normal" business disciplines and continued onto numerous efforts and pretests to solidify the understanding of all aspects of leadership. The ensuing $L Q^{\odot}$ defines leadership as a measure of the precepts/components that are observably crucial when leadership occurs. In this leadership model, positive elements indicate effective or good leadership, and negative elements indicate the opposite. An important triangulation occurs when we witness an effective $L Q^{\odot}$ as a function of the interaction of: 1) Leader, 2) Followers, and 3) Environments (Situations) as shown in $L Q^{\mathcal{C}}$ s formula (and relationally) in Figure 1. 


\section{FIGURE 1}

\section{LEADERSHIP FORMULA}

$L Q \mathcal{C}=$ function of:

Leader's characteristics and traits

$$
\mathrm{DQ}+\mathrm{RQ}+\mathrm{BQ}+\mathrm{AQ}+
$$

Followers' perspectives of leader

$$
\mathrm{CQ}+\mathrm{PQ}+\mathrm{EQ}+\mathrm{IQ}+
$$

Environmental influences and perspectives

$$
\mathrm{XQ}+\mathrm{KQ}+\mathrm{SQ}+\mathrm{MQ}
$$

\begin{tabular}{|c|c|c|}
\hline Abbreviation & Title & Characteristic \\
\hline$D Q:$ & Desire Quotient & Effort, persistence-willingness to do whatever it takes. \\
\hline$R Q:$ & Reality Quotient: & Correctly clarifying inclusiveness, objectives, forward-sightedness, etc. . \\
\hline$E Q:$ & Emotional Quotient: & $\begin{array}{l}\text { Self-awareness, social awareness, empathy, exhibited mood, ability to control first impressions } \\
\text { of self, and level of validity of assessment of self and others. }\end{array}$ \\
\hline IQ: & Intelligence Quotient: & Read more about $L Q$ 's IQ replacement with an SQ. \\
\hline$C Q:$ & $\begin{array}{l}\text { Communications } \\
\text { Quotient: }\end{array}$ & $\begin{array}{l}\text { Verbal, written, body language, dialect, clarity, command, presentation skills, and listening } \\
\text { effectiveness. All of these aspects of communication must fit with the leader's followers and } \\
\text { environment (Service, 2005a). }\end{array}$ \\
\hline$P Q:$ & People Quotient: & $\begin{array}{l}\text { Ability to relate with people; includes relationships, social skills, poise and demeanor, teaming, } \\
\text { networking, etc. }\end{array}$ \\
\hline$B Q:$ & Behavioral Quotient: & $\begin{array}{l}\text { Exhibited external focus, ethics, values, direction, flexibility, savvy, social graces, timing, } \\
\text { inspiration, leader behavior that appeals to the followers. }\end{array}$ \\
\hline$A Q:$ & Appearance Quotient: & $\begin{array}{l}\text { Manifestation of correct level of confidence, appropriate dress, vitality, mannerisms, poise, etc. } \\
\text { and environmental fit from perspective of followers. }\end{array}$ \\
\hline$X Q:$ & eXperience Quotient: & Accomplishments. \\
\hline KQ: & Knowledge Quotient: & $\begin{array}{l}\text { Leader's ability to learn, pay attention, recognize, imagine, and keep up to date on technologies } \\
\text { and other useful knowled ge. }\end{array}$ \\
\hline$S Q:$ & Situational Quotient: & Ability to interpret cues and develop appropriate strategies. \\
\hline$M Q:$ & $\begin{array}{l}\text { Management } \\
\text { Quotient: }\end{array}$ & $\begin{array}{l}\text { General admin skills, systems and proced ures, planning, organizing, controlling, manage (Lane, } \\
\text { 2008; and Hersey, Blanchard and Johnson, 2013). }\end{array}$ \\
\hline
\end{tabular}

Key: 
The Leadership Quotient directs one to realize the traits, abilities, and behaviors that they naturally have and do not have and how to adapt those to followers and environments. After identifying and honing those possibilities (maximizing strengths), figuring out a way around shortcomings (minimizing weaknesses) are keys. This is the application of the "max-min principle" (Service, 2012). This is not a simple on-time task and we are not offering a pseudoscientific pill to cure all leadership problems. "The more complex society gets; the more sophisticated leadership must become. Complexity means change, but specifically it means rapidly occurring, unpredictable, nonlinear change" (Fullan, 2001, p. ix). To the

current authors, this sounds much like crossing cultures. The above quote does not mean there is a need to lead with complexity. Rather, successful leaders are ones that can interpret the difficult and complex and present them in a simplified and understandable way to followers. Leadership can be developed and honed appropriately using the 12 Quotients.

The current authors, as practicing managers, consultants, and professors see management as controlling, arranging, and doing things right. A leader sets visions and does the right things. "[L] eadership plays the prime role for the creation of excellence in an organization" (Kanji \& Moura e Sa, 2001, p. 701). As one moves into the arena of global competition, a shift from managing for stability and control to leadership for speed, experimentation, flexibility, change, and innovativeness becomes critical (Service \& Arnott, 2006). "Leadership is the art of accomplishing more than the science of management says is possible" (Colin Powell, quoted in Harari, 2002, p.13). "I know of no case study in history that describes an organization that has been managed out of a crisis. Every single one of them was led" (General G. J. Flynn in Sinek, 2017, p. xi).

Leadership is human influence occurring as people do things together (Blanchard, 2007). It requires: an understanding of self, others, and environments; learning to balance people, contexts, and tasks; commitment, fit, intellect, principles, desire, and more. A leader's goal should be to help others learn how to fit in yet stand out and make a difference through others. A truly self-perpetuating leader develops others as leaders first and foremost. The road to personal leadership improvement starts with desire and self-awareness, goes on to continuous commitment to development, and ends with practice: application by you and your followers (Yukl, 2013; Zecca et al., 2013).

\section{Leaders' Characteristics and Traits}

Referring to the applicability of $L Q^{\odot}$ as visualized in Figure 2, effective leadership and a satisfyingly successful life require a balanced fit among environments, behaviors, contexts, processes, contents, and needs (Christensen, Allworth, \& Dillon, 2012; Service, 2012; Service \& Arnott, 2006). The GLQ Worldview Strength and Weakness Guide (Figure 3) details the extended $L Q^{\odot}$ precepts one must evaluate against and train for to improve effectiveness in crossing cultures. Max-min principles can be employed to make the best use (maximize) of what you have and to render irrelevant (or minimize) weakness you cannot (or will not) change. Fit and balance are keys to most endeavors. "Do not separate yourself from the community" (Hillel, from Safire \& Safire, 2000, p. 187). "Consider well who you are, what you do, whence you came, and whither you are to go" (English proverb, from Safire and Safire, 2000, p. 209). Learn from the people who not only challenge and conquer the context but who change it in fundamental ways (Bennis, 1989). “... leadership... is about getting alignment and it's about inspiring people to achieve" (Fullan, 2001, p.19). Well-developed systems and organized processes do not become effective until the right people are in the right places for execution of the processes noted here and elsewhere. Great people need to have good processes to be successful. The balance is tough yet powerful when achieved through application of these principles: a) Adapt to followers. b) Fit with environments and tasks. c) Balance self, followers, and the environment. d) Create adaptable "fitability" with time, place, people, and things. e) Fit in before you stand out. 
FIGURE 2

LEADERSHIP SUCCESS TRIANGLE $=$ LQ $\odot$

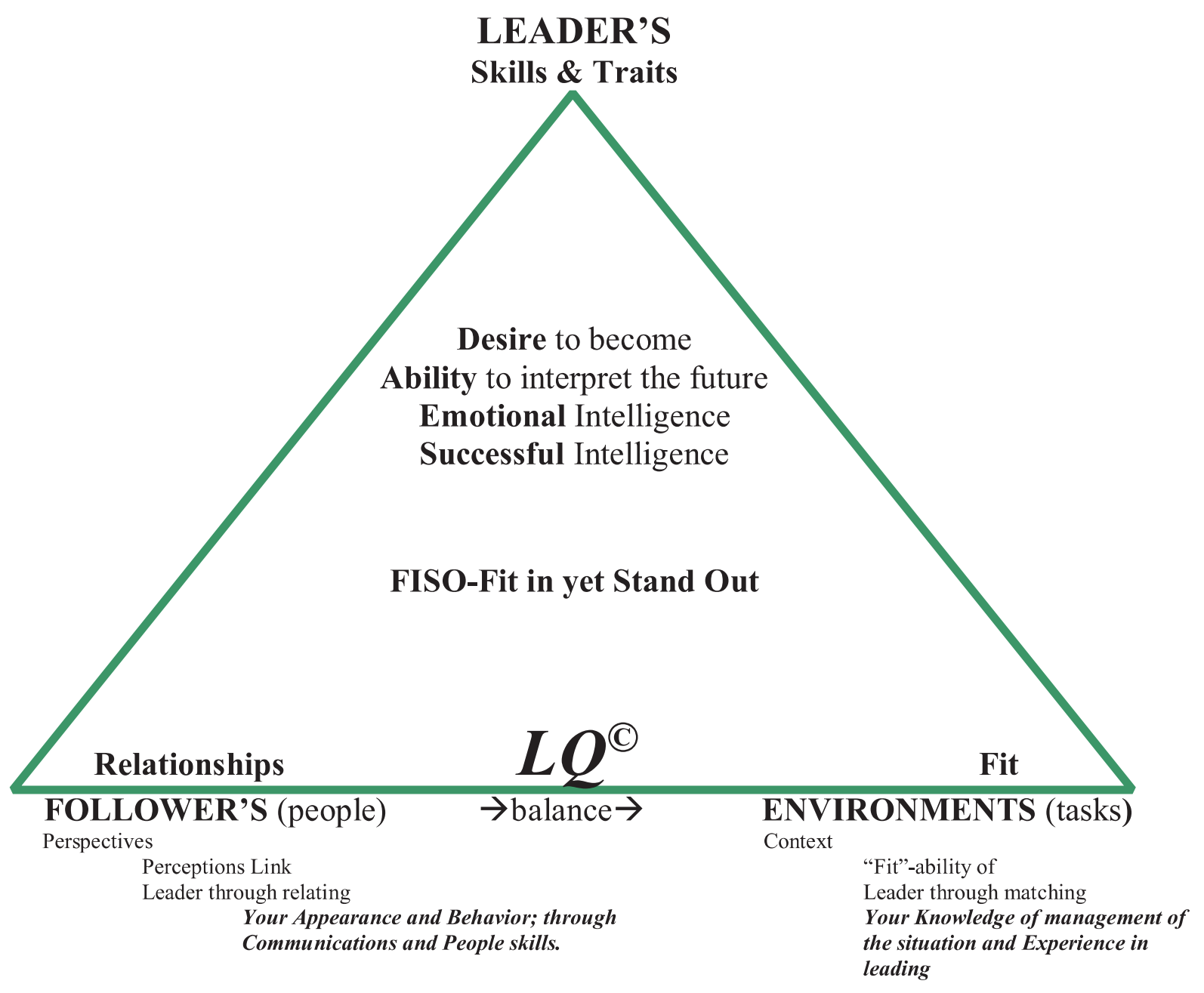




\title{
FIGURE 3 \\ GLQ "WORLDVIEW" STRENGTHS AND WEAKNESSES GUIDE
}

\author{
I. Strengths - advantages, enablers in contextual adaptive development \\ A. Natural* - more uncontrollable 'good' traits-key abilities and attitudes \\ 1. Flexible-openness: equifinality 2 . Dispassionate \\ 3. Flexible gender \& gender orientations 4. Internal locus of control \\ 5. Ability under psychological hardiness 6. Attitudes \& awareness-curiosity \\ 7. Humility \\ 8. Empathic listening \\ 9. Time is theirs \\ 10. Identificational-new as different
}
B. Nurtured - more controllable 'good' traits-key knowledge and skills
1. Known "open" mindsets
2. High social/cultural intellect
3. Weak ethnocentricity
4. Observant
5. Knowledge/skills-job/tasks
6. High EQ
7. Patience
9. Preparation
8. Cultural sensitivity
10. Integrity

II. Weaknesses - disadvantages, derailers to leadership development

A. Natural - more uncontrollable 'bad' traits-key self-centered
1. Strong national affiliation
2. Narcissistic
3. Change avoidance
4. Large power distance
5. Cognitive simplicity
6. Psychological immaturity
7. Fixed worldview
8. Blunt-dogmatic
9. Knows without study
10. Lacks moral compass-integrity
B. Nurtured - more controllable 'bad' traits-key avoidance
1. Disdaining other views
3. Learned behavior pervasiveness
2. Confirming mindset
5. Low EQ
4. Un-accepting of differences
7. Extractionist-to change worldview
6. Relationship challenged
8. Telling over discovering
9. Seeing as right or wrong
10. Timeframes vs. events

* Note: We show as "Natural" traits or mindsets that are formed early and not likely to change. As we indicate throughout this manuscript, our genetic make-up does write the Chapter tiles and even sub-titles of our life stories, but they do not write the complete details of the stories of one's life. Emotional intellect, commonly referred to as $\mathrm{EQ}$, is concept one should understand and practice before managing and leading whether crossing-cultures or not (Bradberry \& Greaves, 2009; and the EQ "guru," Goleman, 1995, 2000).

\section{Leadership Across Cultures}

The first rule of leadership is to understand relationships - to understand the differing logics of achievements and ascriptions (McIntosh, 2011), which vary on a scale from being assigned/ascribed by birth or title to being completely earned. Refusal to send young women into new cultures or to use a surgeon of a different race can be the result of ascription. The opposing perspective would be to select the most proven, effective person without regard to ascribed categories. These decisions can be seen as points along a continuum of doing the same versus doing something new or different (Trompenaars \& Hampden-Turner's, Riding the Waves of Culture, 2012).

Waves brings cultural understanding together with applicable understanding emphasized over categorization. Waves notes that the key differences and biases that must be understood for crossing cultures successfully relate to a spiraling, looping continuum considering: 1) universal versus particular; 2) individual versus community; 3) neutral versus effective; 4) specific versus diffuse; 5) achievement 
versus ascription status; 6) internal versus external control; 7) times as past, present, and/or future (also Bhaskar-Shrinivas, et al., 2005); and 8) sequencing versus synchronicity. We add to this Hofstede's (2001) classic, Culture's consequences: Comparing values, behaviors, institutions, and organizations across nations, as a source that is most often quoted in academic research. For our purposes, Hofstede's five points relate to the eight points just mentioned from Waves. Adding Hofstede's five, we get: 9) power distance; 10) uncertainty avoidance; 11) individualism-collectivism; 12) masculinity-femininity; and 13) long term versus short term orientations.

Before we continue with the Waves points useful in building our model, we would like to weave in applicable concepts from Northouse's (2016) Leadership: Theory and Practice. Northouse presents the following useful concepts: 14) traits; 15) skills; 16) behaviors; 17) situations; 18) path-goal; 19) leadermember exchange; 20) transformational styles; 21) authentic styles; 22) servant styles; 23) adaptive styles; 24) psychodynamic approaches-understand ourselves and our drivers; 25) leadership ethics; 26) teams; 27) gender; and, finally, 28) culture and leadership. When using any classifications, rules, guides, or categories, note that there are often unintended consequences (Conard, 2012).

Now we will add some words that require thought and differing approaches. Change and flexibility; learning; constituency focus; relationships; loyalty; commitment; strategic alignment; teamwork; task orientation; shareholder value; and professional development and structure-corporate, individual, or otherwise. Here we advise that famed author Peter F. Drucker should be a cornerstone for anyone interested in knowing more about these words and how they apply to management and leadership in general (Drucker, 1973, 1985a, 1985b). We then recommend Cohen's (2010) Drucker on Leadership.

Dilemmas arise from the difference in cultural diversity, though that variability is extremely valuable to organizations especially in innovating (Abernathy \& Utterback, 1988). For example, as well as it works at times and as much as we teach it, paying for performance may fail in many cultures. The challenge is to find out where. However, this pay for superior performance is the new model in the U.S. healthcare system, codified with MACRA (Medicare Access and CHIP Reauthorization Act, n.d.). A key is to remember that across the world, things are not valued the same, and all things are experienced differently according to overriding cultural differences (Service \& Carson, 2013). Culture is different everywhere, and culture defines the preferences, norms, and ways people define, solve, and ignore problems and issues. Even within cultures there are professional, educational, farm, urban, and other subcultures (Arnott, 2000; Sarros, Cooper, \& Santora, 2008). Context, context, context is the overriding idiom for crossing cultures, just as location, location, location is for real estate. There are alternate facts (Allison, 2013; Baumohl, 2005; Blair, 2010; Bush, 2010; Kennedy, 1987; Rumsfeld, 2013). One must consider whose facts, where are they, why are they, and how they are being used to define the multiplicity of duplicitous "facts." People perceive phenomena in many differing orderly or less orderly ways, in sensible or nonsensical ways based on overarching culture.

Productive and informative cultural intelligence (CQ) researchers Earley and Mosakowski (2016) rightly proclaim that "Rote learning about the beliefs, customs, and taboos of foreign cultures, the approach corporate training programs tend to favor, will never prepare a person for every situation that arises, not will it prevent terrible gaffes [p. 5]... Unlike other aspects of personality, cultural intelligence can be developed in psychologically healthy and professionally competent people... The individual examines his CQ strengths and weaknesses in order to establish a starting point for subsequent development efforts" (p. 13).

The GLQ provided in this manuscript provides the most comprehensive comparative tool currently available for CQ comparative and improvement purposes. Finally, these researchers warn against solely relying on "tech" for communication, pronouncing that in person face-to-face is still the richest form of communication. But in an ecommerce era, many leaders will cross cultures without even leaving home.

Our own cultures are like water to a fish, and we have to get out of the water before we miss it. The humanness of thought makes cultural variables and variations not normally distributed and requires that our GLQ be taken over spectrums - not as a dichotomy. Generalizations and generations vary the strength, form and directionality of variables (Ang \& Van Dyne, 2008). If problems and definitions vary by culture, one can expect solutions to vary, as well. 
As we get deeper into Waves, we are weaving other research, observations, stories and examples. The current authors, having hired, fired, taught, and consulted with thousands over the years, see Waves as solidifying our belief that there is no "demonstrably fair and universal way of managing" (Trompenaars \& Hampden-Turner, 2012, p. 55). This leads to the conclusion that the only real answers to the complex question of leading or managing across cultures are themselves questions. Furthermore, the "just different" scale of extremes on the 28 cultural dimensions listed earlier are not straight lines but more like corkscrew circles that spiral back into themselves. The old idea of right and wrong represented as being on the line or linear must be reconsidered (Csikszentmihalyi, 1990; Elmer, 2002). A continuum representation is better than a binary choice, but we suggest it actually it looks more like Figure 4, which simply loops back in on itself.

\section{FIGURE 4 \\ REALITY OF ADAPTATION}

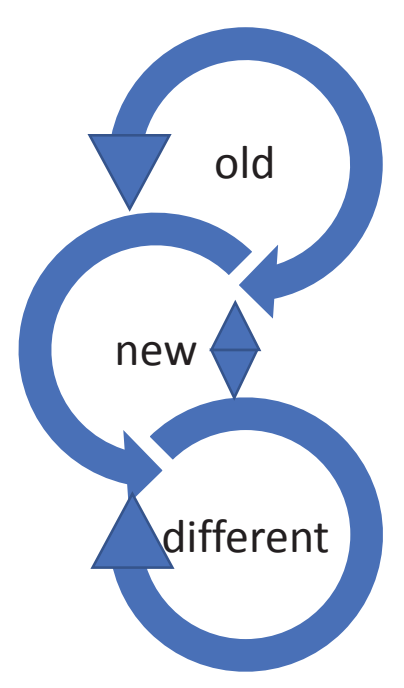

In Figure 4, we see key competencies, old or new, are not definite and complete. It is a challenge to reconcile dilemmas to a complementary degree that both sides can accept. This compromising will tie into our GLQ Model being presented here with the realization that answers depend on circumstances. Selfrealization, reconciliation, and "universal otherhood" (Waves, p. 73) can be tough concepts to grasp. For example, when one of the authors was in Kenya, he felt better when he realized that the rules as he had known them about age, gender, social conation, professionalism, and more were treated there more like suggestions than rules (Service, Loudon, \& Kariuki, 2014; Stalk \& Hout, 1990). And "African time" reverted back to the 2-year-old who easily understands now and not now with little concern for the concept of yesterday or tomorrow.

Another important work, Meyer's (2014) The Culture Map: Breaking through the Invisible Boundaries of Global Business, clearly explains the importance of understanding diverse styles of communication and leading in different cultures. Culture Map espouses that seven key aspects of crosscultural leadership are useful as evaluative scales for guiding communication, evaluation, leading, decision-making, trust, disagreement, and scheduling. Meyers notes that cultures have commonalities in these areas, but existing differences require broadening understandings. For example, Chinese and Japanese cultures have great similarity in their communication and leadership perspectives, but they are very different in decision-making. Therefore, Meyer encourages greater intentionality in seeking understanding of the corresponding cultures where one is seeking to work as an outsider (also see Meyer, 2017).

When comparing the U.S. and China, "high power distance" is a common challenge in cooperative situations. The Culture Map scale depicting attitudes towards authority puts China far on the hierarchical 
side compared to an egalitarian approach to leadership in U.S. An author of this current manuscript has viewed this dynamic causing tensions in higher education partnerships between China and the U.S. In one example, the president of the U.S. educational institution had a very egalitarian attitude toward leadership, which led to misunderstanding the importance of the primary leader in Chinese culture. The American university's president noted that "the provost is really in charge of most of the important decisions" and, therefore, the president decided to skip the meeting with the Chinese University. The international cooperation offices in China were very upset about this decision. Consequently, the Chinese university's president did not show up and nothing of significance resulted from the meeting.

As professionals, we all like plans or strategies and say "don't leave home without them," for your competitors and distractors have them. Strategy defines which choices you should make to reach desired and defined goal and objectives (Mintzberg, Ahlstrand, \& Lampel, 2005). Useful and correct mutuality requires level playing fields, and nothing makes for a slanted table like one person with strategy and the other without. We see strategy books filled with differing labels for people professionals will encounter from silly titles such as guided missiles to directors, reactors, defenders, analyzers, prospectors, and more (Bennis, 1989; Broom et al., 2014; Porter, 1980, 1985, 1990). Of course, you have to know the types of others and work toward understanding your own if you want to win in a new cultural arena.

What we have presented here is a guide for knowing biases, traits, skills - precepts - that can direct or misdirect thinking and impede or aid teaching and learning. Whether or not our GLQ is useful to you will be more about you than our model. "Banishing our conscious and unconscious biases and adopting a mindset of openness expands, enriches, and diversifies our point of view... Be adventurous, creative, and open-minded... Build open and honest relationships with communications" (Tjan, 2017, p. 74 and 75).

\section{THE GLQ MODELS}

Using our extensive literature review and $L Q^{\odot \text {, }}$ research (described more fully in Service \& Carson, 2013), we see our GLQ Models (Figures 3 and 5) must revolve around intentionality (Glynn \& Giorgi, 2013). Vigilant attention and sustained effort to understand the precepts represented in our models will help interested individuals maximize strengths and minimize or deflect weaknesses, thereby moving one more step toward successful cross-cultures experiences.

Today's world of global business requires that companies must "innovate by learning from the world... transform[ing] individuals in ways that make them more valuable employees [p. 129]... [T] oday's leadership will not be sufficient for the future [p. 50]... The passion to make a difference and the willingness to allow others to participate in creating it is more likely to lead to leadership success than simply acquiring and checking off a list of skills" (Mendenhall et al., 2008, p. 62).

\section{Cross-cultural Leadership for the Rest of Us (Figures 3 and 5)}

All principles and precepts are amalgamated or extrapolated into Figure 3, which is our comprehensive GLQ Worldview Strength and Weakness Guide that details the extended $L Q^{\odot}$ precepts derived in this research. Here one must evaluate against and or train for effectiveness in crossing cultures by understanding and evaluating all their capabilities and knowledge shown in the concepts depicted in Figure 3. Then to improve, one must use the max-min principles to maximize the best use of what one has and to minimize or render irrelevant weakness one cannot or will not change. In the Global Leadership Effectiveness Model depicted in Figure 5, we see the relationships and related precepts that you must master to become a well-rounded cross-cultural leader. This overriding final model (Figure 5) provides a comprehensive view of leading innovativeness in ever-changing global environs. Drucker said becoming a more effective leader for innovation is possible if it becomes a life-long self-development activity (Buford, 2014; Cohen, 2010). Drucker stressed the fact that people can learn to be more innovative and more effective leaders and concludes much of his writing by saying not only can we all improve, but that we must continue progressing in these areas if our society is to continue to progress. The learning never ends if cross-cultural intellect is the objective (Blasco, Feldt, \& Jakobsen, 2012). Our models can jump 
start and bookend efforts toward measuring and improving cross-cultural capabilities-innovation exemplified in application.

FIGURE 5

GL $Q^{\odot,}$ S GLOBAL LEADERSHIP EFFECTIVENESS MODEL

Individual Realism - personal \& professional

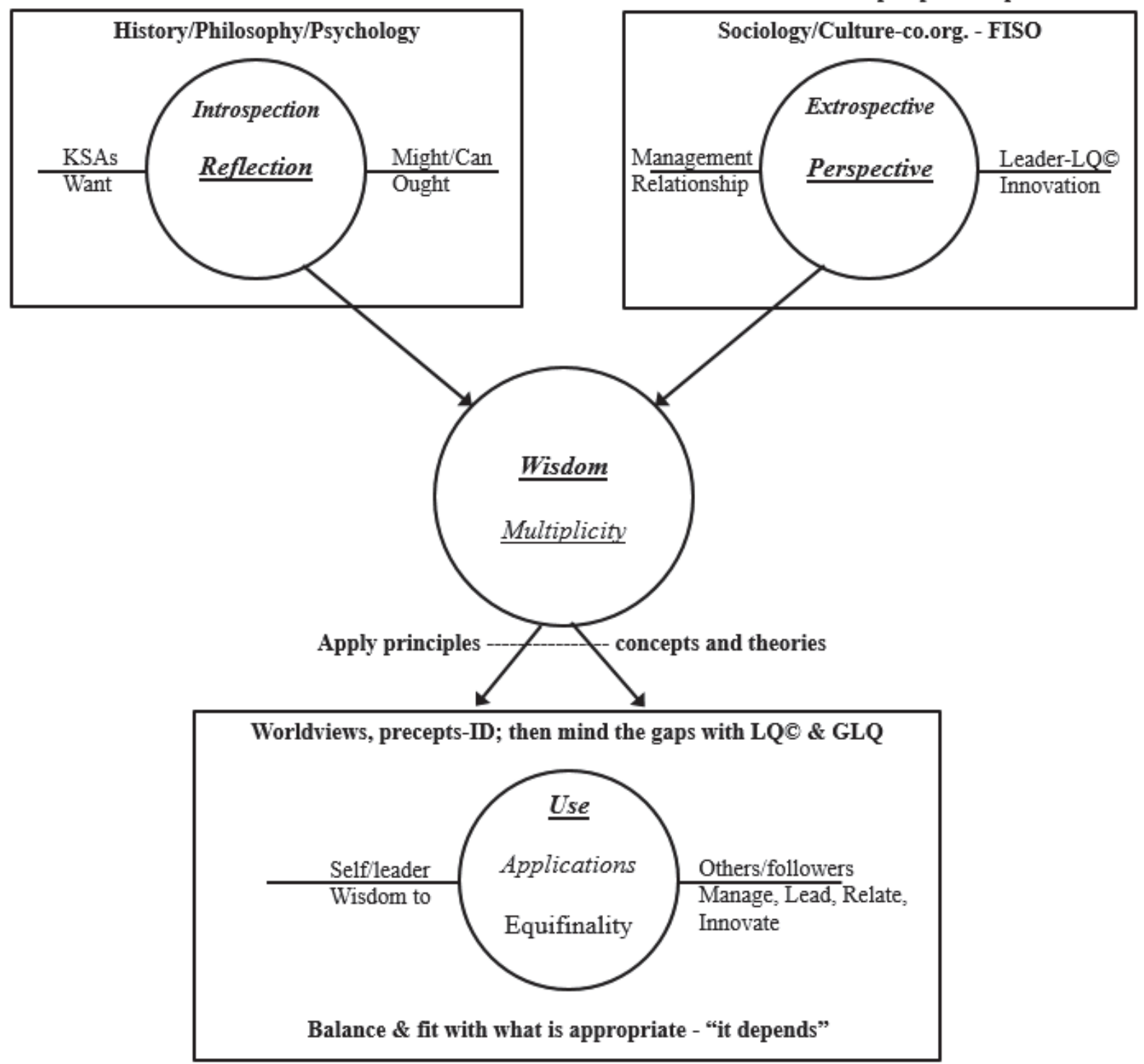




> Sweet spots are intersections that satisfice through optmizing differing perspectives in a
balanced and appropriate way that fits the people and situations: it depends!
$>$ The multiplicity of wisdom is knowing variables of what "it" depends on and being able to apply
"it."
$>$ Effectiveness of personal, professional, emotional and intellectual cosmopolitanism, discipline
specific acumen and relational abilities merge to form GLQ worldviews.
$>$ GLQ revolves around generalizeable reflective, relational, analytical, creative, applicable,
worldly,
collaborative and action orientated mindsets (Service, 2012; Mintzberg, 2004, 2009).
Equifinality-indicates there are many ways to the same or equally good ends.
Success in global leadership requires worldviews that are useful across varied contexts.

The GLQC model is the amalgamation of sweet-spots of leadership effectiveness as the "wisdom" to balance combinations and permutations of circumstances within characteristics and knowledge that provide a timely fit for the involved people in the proper manner. Focus must be on analyzing yourself, others, and situations and applying new-found knowledge to improve leadership effectiveness in the evermore complex contexts of leading innovation.

\section{How Do We Apply?}

GLQ Model 5, and to a lesser extent Figure 3, show influences of worldviews and leadership concepts coming together to foster applying all parts of the other sub-models by using relevant earned and learned relational, management, and leadership wisdoms. "Wisdoms" can't be reduced to principles or secrets presented by the rich and famous (Gladwell, 2002, 2005, 2008). The GLQ provides a roadmap toward becoming a cross-cultural leader capable of understanding the wisdom sweet-spots of varied reflections, perspectives, and extro-and introspections.

"All generalizations are false-including this one" (Rumsfeld, 2013, p. xiii). That is, rules can never replace considered judgment nor can models replace base values. Situations and all those involved are at best slightly different. Recognizing the appropriate differences and applying all principles in a balanced way is cross-cultural wisdom. Contemplate another warning from Rumsfeld: "What should they know of England who only England know?" (citing Rudyard Kipling, p. 106). An inside-only view is seldom a fully intentionally useful reality. Consider GLQ as a bridge to success in another culture that is supported by the solid "rest-of-us" leadership paradigm.

\section{An Important Reminder Warning for Us and Our Readers About Religion}

When crossing-cultures for business reasons, do not "witness" with your words to others about your faith (Broom \& Service, 2014). Your witness needs to be your actions and how you speak. Your actions speak louder than any words. Treat people with kindness, respect, and the utmost honesty, but hold off on the preaching until you are in a place of worship.

\section{CONCLUSIONS}

Though we present and espouse models and principles in this manuscript, we want to remind the reader that understanding must preclude labelling, and principles override models. Cultures are powerful and they feed or starve innovation, learning, and progress. However, cultures do evolve, and they can be directed. Cultures, be they broad societal norms, more local norms, or organizational-specific, need to be adhered to to a degree. The key is to first know then do, and you will then become the leader you want and need to be in the cultures within which you must act (Service, Reburn, \& Windham's (2017) "Know Do Be" model is very useful here). Those complete cultural directions are beyond this manuscript and are 
for a future study. Our chief aim is to help readers fit into a culture before they stand out and attempt to direct any aspect of culture.

In the scope of this manuscript, the literature is clear on crossing-cultures requirements, and an incorporation of our models shows how to meet those needs to: 1) develop people with the right knowledge, skills, and abilities that are willing to work for success in global leadership (Earley \& Ang, 2003); 2) Find people with the relatively rare and correct balance of knowledge, skills, and abilities required for crossing cultures (Caligiuri, 2006). 3) Use comprehensive interdisciplinary approaches to research in this area (Bate \& Child, 1987). 4) Comprehend that global leadership occurs in a world of varied complexity, with interactive patterns among subunits of many varied constituents with pressures for stability and change (Crowne, 2013). 5) Measure for the development of the wisdom of leadership and culturally-appropriate actions requires a life-long commitment to searching and learning (Elmer, 2002). 6) Reassess your or your organization's competitive identity in this web of global relationships (Hofstede, 2001). 7) Understand foundational requirements for power, feelings, concerns, dependences, collaborations and competition, and team and individual efforts across cultures (Bhaskar-Shrinivas et al., 2005; Lencioni, 2002; Mendenhall et al., 2008).

Effective influence through leaders - global or otherwise - is characterized by ambiguously complex interrelated relationships, communications, values, missions, motivations, and visions (Gundling, 2003; Kupka \& Cathro, 2007; Lee, 2005, 2009; Lee \& Sukoco, 2008; Service \& Arnott, 2006). This complexity shows when one views the varied constituents commanding attention with their all-too-often mutually exclusive desires (Furrer, Tjemkes, Aydinlik, \& Adolfs, 2012; Takeuchi, 2010; Takeuchi, Yun, \& Tesluk, 2002). It seems "unconscious processes are better when everything is ambiguous [p. 243]... [Acquire] a set of practical skills that enable [you] to anticipate change" (Brooks, 2011, p. 249).

Identify and modify your habits. Habits are always with us, and they are responsible for our failures and successes (Covey, 1990 (all Covey's works are good for preparing for cross cultural experiences)): Habits will make or break your attempts to be more effective at crossing cultures (Dorner, 1996).

Without a doubt, every thinking human wants to feel appreciated and have something to build their lives around. Leaders and managers must give them those things regardless of cultures involved. Additionally, "What people want in leaders today, more than ever before, is integrity-walking their talk" (Blanchard in Despain \& Converse, 2003, p. xvii; also see Shinn, 2011)." J. Dennis Hastert, Speaker of the House (Despain \& Converse, 2003: first unnumbered introductory page): "I have come to understand the truth behind the saying "leaders aren't born, they are made." Despain and Converse (2003) based their book on a lifetime of experiences, and they espoused that the key is values defined with shared beliefs coupled with standards for workplace behaviors. "Leadership is about others and not about self" (p. xxii). James Despain says, "I give people freedom to handle work their own way, I listen more than I talk, I work with every employee to create a development plan, and I say something positive to every employee in my group every day" (p. 148). Indeed, leaders and managers must move from a control-based leadership to a values-based leadership model, which is one that basically defines working across cultures effectively.

Leaders and managers need enough intellect to handle the tasks, but they also must motivate, guide, inspire, listen, know how to gain consensus, teach and learn, innovate, anticipate, and analyze regardless of setting or cultures of those they lead (Maxwell, 2000, 2002, 2006; Pink, 2009). Leaders must ultimately move and act to get others to do so. To do this requires much beyond talent and requires principles of discipline, endurance, love, and luck. The principles presented and tested here can lead one to a lifetime desire for the needed shift toward a more effective way of leveraging people for innovation (given the desire and effort) regardless of cultural norms or settings.

Shift from seeking confirming evidence to seeking disconfirming evidential views. We tend to accept 100 percent of confirming evidence and very little that goes against our beliefs. Successfully crossing cultures requires truth, image, clarity, intention, curiosity, flexibility, and innovation of self and related mindsets.

Humans are self-interested beings that are moral and cognitive. We have evolved to understand and use the mutual benefit of "honest" cooperation in our societal cultures (Pinker, 2011). Cultural differences 
exist on an honesty scale that is mostly determined by "The Influentials" within a society (Keller \& Berry, 2003). Be one of those 10\% identified Influentials guiding cultures to improve mutual outcomes in order to flourish in an ever-flattening global stage. In these arenas (familial, communal, global-personal and organizational) set your self-expectations at a level that are difficult to realize. Push yourself to succeed in new cultures.

\section{REFERENCES}

Abernathy, W.J., \& Utterback, J.M. (1988). Innovation over time and in historical context. Readings in The Management of Innovation, 2, 25-36.

Albrecht, K. (2003). The power of minds at work. New York, NY: AMACOM.

Allison, J.A. (2013). The financial crisis and the free market cure. New York, NY: McGraw-Hill.

Ang, S., \& Van Dyne, L. (2008). Conceptualization of cultural intelligence: Definition, distinctiveness, and nomological network. Ang, S. and Van Dyne, L. (eds.), Handbook on cultural intelligence: Theory, measurement and applications. Armonk, NY: M.E. Sharpe, 3-15.

Arnott, D. (2000). Corporate cults: The insidious lure of the all-consuming organization. New York, NY: AMACOM.

Bate, P., \& Child, J. (1987). Paradigms and understanding in comparative organizational research, in Child, J. and Bate, P. (eds.), Organization of innovation East-West perspective, New York, NY: Walter de Gruyter, 19-49.

Baumohl, B. (2005). The secrets of economic indicators. Upper Saddle River, NJ: Wharton School Publishing.

Bell, R.G., Filatotchev, I., Kruse, R., \& Hitt, M.M. (2018). From the guest editors: Opportunities and challenges for advancing strategic management education. Academy of Management Learning and Education, 17(3), 233-240.

Bennis, W.G. (1989). On becoming a leader. Reading, MA: Addison-Wesley Publishing Co.

Bhaskar-Shrinivas, P., Harrison, D., Shaffer, M., \& Luk, D.M. (2005). Input-based and time-based models of international adjustment: Meta-analytic evidence and theoretical extensions. Academy of Management Journal, 48(2), 257-281.

Blair, T. (2010). A journey: My political life. New York, NY: Alfred A. Knopf.

Blanchard, K. (2007). Leading at a higher level. New York, NY: Prentice Hall.

Blasco, M., Feldt, L.E., \& Jakobsen, M. (2012). If only cultural chameleons could fly too: A critical discussion of the concept of cultural intelligence. International Journal of Cross Cultural Management, 12(2), 229-245.

Blinder, A.S. (2018, April 18). What they don't teach in Econ 101. The Wall Street Journal, A13.

Bradberry, T., \& Greaves, J. (2009). Emotional intelligence 2.0. San Diego, CA: TalentSmart.

Brooks, D. (2011). The social animal: The hidden sources of love, character, and achievement. New York, NY: Random House.

Broom, L.S., \& Service, R.W. (2014). Religion or psychology? Making the case for economic and organizational impact. Business Renaissance Quarterly, 9(1-2), 51-83.

Broom, L., Loudon, D. L., Service, R.W., \& Sonius, D. (2014). Rapid incremental innovation strategy: Sustainable competitive advantage. International Journal of Engineering Research \& Management, 1(6), 50-58.

Buckingham, M. \& Clifton, D.O. (2001). Now, discover your strengths. New York, NY: The Free Press.

Buford, B. (2014). Drucker \& me: What a Texas entrepreneur learned from the father of modern management. Brentwood, TN: Worthy Publishing.

Bush, G.W. (2010). Decision points. New York, NY: Crown.

Caligiuri, P.M. (2006). Developing global leaders. Human Resource Management Review, 16, 219-228.

Chopra, D., \& Mlodinow, L. (2011). War of worldviews. New York, NY: Harmony Books.

Christensen, C.M., Allworth, J., \& Dillon, K. (2012). How will you measure your life? New York, NY: Harper Business. 
Cohen, W.A. (2010). Drucker on leadership: New lessons from the father of modern management. San Francisco, CA: Jossey-Bass.

Colino, A., Benito-Osorio, D., \& Armengot, C.R. (2014). How much does innovation matter for economic growth? Management Decision, 52, 313-325.

Collins, J. (2001). Good to great: Why some companies make the leap to greatness and others don't. New York, NY: HarperCollins.

Collins, J. (2003, July 21). The 10 greatest CEOs of all time. Fortune, 55-68.

Conard, E. (2012). Unintended consequences: Why everything you've been told about the economy is wrong. New York, NY: Penguin.

Covey, S. (1990). The 7 habits of highly effective people. New York, NY: Simon \& Schuster.

Crowne, K.A. (2013). Cultural exposure, emotional intelligence, and cultural intelligence: An exploratory study. International Journal of Cross Cultural Management, 13(1), 5-22.

Csikszentmihalyi, M. (1990). Flow: The Psychology of Experience. New York, NY: Harper Perennial.

Despain, J. \& Converse J.B. (2003). And dignity for all. Upper Saddle River, NJ: Prentice Hall.

Dobelli, R. (2013). The art of thinking clearly. (N. Griffin, Trans.) New York, NY: HarperCollins.

Dorner D. (1996). The logic of failure: Why things go wrong and what we can do to make them right. New York, NY: Henry Holt and Company.

Drucker, P.F. (1973). Management: Tasks, responsibilities, practices. New York, NY: Harper \& Roe.

Drucker, P.F. (1985a). Innovation and entrepreneurship. New York, NY: Harper \& Roe.

Drucker, P.F. (1985b). The discipline of innovation in HBR's 10 Must Reads on Innovation, 2013. Boston, MA: Harvard Business Review Press, 143-156.

Earley, P.C. \& Ang, S. (2003). Cultural intelligence: Individual interactions across cultures. Stanford, CA: Stanford University Press.

Earley, P.C. \& Mosakowski, E. (2004). Cultural intelligence. Harvard Business Review, 82(10), 139-146.

Elmer, D. (2002). Cross-cultural connections: Stepping out and fitting in around the world. Downers Grove, IL: IVP Academics.

Frank1, V.E. (2006). Man's Search for Meaning. Boston, MA: Beacon Press.

Fullan, M. (2001). Leading in a Culture of Change. San Francisco: Jossey-Bass.

Furrer, O., Tjemkes, B.V., Ülgen Aydinlik, A., \& Adolfs, K. (2012). Responding to adverse situations within exchange relationships: The cross-cultural validity of a circumplex model. Journal of Cross-Cultural Psychology, 43(6), 943-966.

Gladwell, M. (2002). The tipping point: How little things make a big difference. Boston, MA: Little, Brown.

Gladwell, M. (2005). Blink: The power of thinking without thinking. New York, NY: Little, Brown and Company.

Gladwell, M. (2008). Outliers: The story of success. New York, NY: Little, Brown and Company.

Glynn, M.A. \& Giorgi, S. (2013). Taking the cultural turn: Reading cultural sociology. The Academy of Management Review, 38(3), 466-470.

Goleman, D. (1995). Emotional intelligence. New York, NY: Bantam Books.

Goleman, D. (2000). Working with emotional intelligence. New York, NY: Bantam.

Haidt, J. (2012). The righteous mind: Why good people are divided by politics and religion. New York, NY: Vintage Books.

Hall, S.S. (2011). Wisdom: From philosophy to neuroscience. New York, NY: Vintage.

Harari, O. (2002). The leadership secrets of Colin Powell. New York, NY: McGraw-Hill.

HBR's 10 Must Reads: On Managing Across Cultures. (2016). Boston, MA: Harvard Business Review Press.

Hofstede, G. (2001). Culture's consequences: Comparing values, behaviors, institutions, and organizations across nations. Thousand Oaks, CA: Sage.

Hunger, J.D., \& Wheelen, T.L. (2011). Essentials of strategic management (5th ed.). Upper Saddle

River NJ: Prentice Hall.

116 Journal of Business Diversity Vol. 19(3) 2019 
Kanji, G.K., \& e Sa', P.M. (2001). Measuring leadership excellence. Total Quality Management, 12(6), 701-718.

Keller, E. \& Berry, J. (2003). The influentials. New York, NY: The Free Press.

Kennedy, P. (1987). The rise and fall of the great powers, New York, NY: Random House.

Kupka, B. \& Cathro, V. (2007). Desperate housewives-social and professional isolation of German expatriated spouses. The International Journal of Human Resource Management, 18(6), 951-968.

Lee, H.K. (2005). Rethinking arts marketing in a changing cultural policy context. International Journal of Nonprofit and Voluntary Sector Marketing, 10(3), 151-164.

Lee, H.K. (2009). Between fan culture and copyright infringement. Media, Culture \& Society, 31(6), 1011-1022.

Lee, L.Y., \& Sukoco, B.M. (2008). The mediating effects of operational capability on the success of expatriation, Social Behavior and Personality, 36(9), 1191-1204.

Lencioni, P. (2002). The five dysfunctions of a team. San Francisco, CA: Jossey-Bass.

Maxwell, J.C. (2000). The 21 most powerful minutes in a leader's day. Nashville, TN: Thomas Nelson, Inc.

Maxwell, J.C. (2002). Leadership 101: What every leader needs to know. Nashville, TN: Thomas Nelson, Inc.

Maxwell, J.C. (2006). The 360 degree leader. Nashville, TN: Thomas Nelson.

McIntosh, F. (2011). The relational leader: A revolutionary framework to engage your team. Boston, MA: Course Technology.

Medicare Access and CHIP Reauthorization Act: H.R. 2, $114^{\text {th }}$ Congress. (n.d.). Retrieved from https://www.congress.gov/bill/114th-congress/house-bill/2/text

Mendenhall, M.E., Osland, J.S., Bird, A., Oddou, G.R., \& Maznevski, M.L. (2008). Global leadership: Research, practice and development. New York, NY: Routledge.

Meyer, E. (2014). The culture map: Breaking through the invisible boundaries of global business. New York, NY: Public Affairs.

Meyer, E. (2017). Being the boss in Brussells, Boston, and Beijing. Retrieved from https://hbr.org/2017/07/being-the-boss-in-brussels-boston-and-beijing

Mintzberg, H. (2004). Managers not MBAs: A hard look at the soft practice of managing and management development. San Francisco, CA: BK Publishers.

Mintzberg, H. (2009). Managing. UK: Pearson Education.

Mintzberg, H., Ahlstrand, B., \& Lampel, J. (2005). Strategy bites back. Upper Saddle River, NJ: Pearson Prentice Hall.

Northouse, P.G. (2016). Leadership: Theory and practice ( $7^{\text {th }}$ edition). Los Angles, CA: Sage.

Pink, D.H. (2009). Drive: The surprising truth about what motives us. New York, NY: Penguin.

Pinker, S. (1997). How the mind works. New York, NY: W.W. Norton.

Pinker, S. (2002). The blank slate: The modern denial of human nature. New York, NY: Viking.

Pinker, S. (2011). The better angles of our nature: Why violence has declined. New York, NY: Penguin.

Porter, M.E. (1980). Competitive strategy. New York, NY: Collier Macmillan.

Porter, M.E. (1985). Competitive advantage. New York: Macmillan.

Porter, M.E. (1990). The competitive advantage of nations. New York, NY: Macmillan.

Powell, T.C. (2017). Strategy as diligence: Putting behavioral strategy into practice. California Management Review, 59(3), 162-190.

Rumsfeld, D. (2013). Rumsfeld's rules. New York, NY: Broadside Books.

Saba, A.S. (2011). Roll the dice: Are we gambling with global employee selection? A reassessment of competitive alternatives. Proceedings of The International Academy of Business and Public Administration Disciplines (388) (Abstract only published). Memphis, TN.

Safire, W. \& Safire, L. (2000). Leadership. New York, NY: Galahad Books.

Sarros, J.C., Cooper, B.K. \& Santora, J.C. (2008). Building a climate of innovation through transformational leadership and organizational culture. Journal of Leadership \& Organizational Studies, 15(2), 145-158. 
Service, R.W. (2012). Leadership and innovation across cultures: CIQ-contextual effectiveness as a skill, Southern Business Review, 37(1), 19-50.

Service, B., \& Arnott, D. (2006). The leadership quotient: 12 dimensions for measuring and improving leadership. New York, NY: i Universe.

Service, R.W. \& Carson, C.M. (2013). Cross-cultural leadership: A roadmap for the journey. Academy of Contemporary Research Journal, V(II), 29-40.

Service, R.W., Loudon, D.L., \& Kariuki, K. (2014). Cross-cultural leadership: Recommendations for Kenya. Journal of Social Economics Research, 1(4), 40-71.

Service, R.W., \& Reburn, J.P. (2014). Leadership for innovation: Fundamentals of human influence. Journal of International Business Research and Practice, V(8), 35-76.

Service, R.W., \& Reburn, J.P. (2016). Academic publication and issues of the day: U.S. income tax paradigm. Archives of Business Research, 4(6), 178-208.

Service, R.W., Reburn, J.P., \& Windham, J.R. (2017). The character of leadership: Is leadership. European Journal of Management, 17(2), 49-72.

Shinn, S. (2011). The customizable curriculum. BizEd, 10(5), 32-37.

Sinek, S. (2017). Leaders eat last: Why some teams pull together and others don't. New York, NY: Penguin.

Stalk, G. Jr., \& Hout, T. M. (1990). Competing Against Time. New York: Macmillan.

Statistics of Income (n.d.). Retrieved July 30, 2016 from https:/www.irs.gov/pub/irssoi/13CorporateReturnsOneSheet.pdf

Sternberg, R.J. (1985). Beyond IQ: A triarchic theory of human intelligence. New York, NY: Cambridge University.

Sternberg, R.J. (1988). The triarchic mind. New York, NY: Viking Penguin.

Sternberg, R.J. (1996). Successful intelligence: How practical and creative intelligence determine success in life. New York, NY: Simon \& Schuster.

Sternberg. R.J. (2003). Wisdom, intelligence, and creativity synthesized. New York, NY: Cambridge University Press.

Takeuchi, R. (2010). A critical review of expatriate adjustment research through a multiple stakeholder view: Progress, emerging trends, and prospects. Journal of Management, 36(4), 1040-1064.

Takeuchi, R., Yun, S., \& Tesluk, P.E. (2002). An examination of crossover and spillover effects of spousal and expatriate cross-cultural adjustment on expatriate outcomes. Journal of Applied Psychology, 87(4), 655.

Tjan, A. (2017). Good people: The only leadership decision that really matters. New York, NY: Portfolio.

Trompenaars, F., \& Hampden-Turner, C. (2012). Riding the waves of culture: Understanding diversity in global business $\left(3^{\text {rd }}\right.$ ed.). Boston, MA: Nicholas Brealey.

Wood, P. \& Randall, D. (2018, April 17). How bad is the government's science? The Wall Street Journal, A17.

Yukl, G. (2013). Leading in organizations (8th ed.). Boston, MA: Pearson.

Zecca, G., Verardi, S., Antonietti, J.P., Dahourou, D., Adjahouisso, M., Ah-Kion, J., Amoussou-Yeye, D. ... Rossier, J. (2013). African cultures and the five-factor model of personality: Evidence for a specific pan-African structure and profile? Journal of Cross-Cultural Psychology, 44(5), 684700.

118 Journal of Business Diversity Vol. 19(3) 2019 